\title{
GENETIC DIVERSITY OF EGYPTIAN ARABIAN HORSES FROM EL-ZAHRAA STUD BASED ON 14 TKY MICROSATELLITE MARKERS
}

\author{
Mary A. N. Sargious ${ }^{1,2}$, Ragab M. El-Shawarby², Mohamed E. Abo-Salem², Elham A. EL-Shewy², Hanaa A. Ahmed', Naglaa M. \\ Hagag $^{1}$, Sherifl. Ramadan ${ }^{3 *}$ \\ ${ }^{1}$ Genome Research Unit, Animal Health Research Institute, Dokki, Giza, ${ }^{2}$ Department of Forensic Medicine and Toxicology, Faculty of \\ Veterinary Medicine, Benha University, ${ }^{3}$ Department of Animal Wealth Development, Faculty of Veterinary Medicine, Benha University, \\ Moshtohor, Toukh 13736, Qalyubia, Egypt \\ ${ }^{*}$ Corresponding author, E-mail: sherif.ramadan@fvtm.bu.edu.eg
}

\begin{abstract}
The objectives of this study were, firstly, to conduct genetic characterization of Egyptian Arabian horses based on 14 TKY microsatellite markers, secondly, to investigate the powerfulness of these 14 TKY markers for parentage assignment of Arabian horses. A total of 101 horse samples including (Arabian $=71$, Thoroughbred $=19$ and Nooitgedacht $=11$ ) were analysed by 14 TKY microsatellite markers. The PCR products were electrophoresed on Genetic analyzer 3500 with the aid of Liz standard. The basic measures of the allele's size and genetic diversity were computed using bioinformatics software. The polymorphism of the TKY markers across the Arabian population showed moderate values for genetic diversity parameters; number of allele $\left(N_{A}\right)=8.143$, effective number of allele $\left(N_{e}\right)=3.694$, observed heterozygosity $\left(H_{0}\right)=0.599$, expected heterozygosity $\left(H_{E}\right)=0.691$, polymorphic Information Content $(\mathrm{PIC})=0.636$ and Inbreeding coefficient $\left(\mathrm{F}_{\mid \mathrm{S}}\right)=0.128$. The combined probability of exclusion (CPE) value of the 14 TKY microsatellite loci of our Arabian horses was 0.9999 . The results from current study confirm the applicability and efficiency of $T K Y$ microsatellite panel for evaluating the genetic diversity and parentage assignment of Egyptian Arabian horses.
\end{abstract}

Key words: Arabian horses; genetic diversity; microsatellite; TKY markers

\section{Introduction}

Arabian horse is commonly believed to be one of the oldest and the most influential breed in the world. It is the most valuable and expensive breed as it combines the beauty of the body, fitness, agility, and intelligence as well (1). It is believed to be an immediate progenitor of many horse breeds including the Thoroughbred and Nooitgedacht (2-4). Nooitgedacht is a South African horse breed developed in 1951 as an attempt to save the endangered Basuto Pony (2). During the early colonial era in Southern Africa, the first

Received: 19 January 2020

Accepted for publication: 10 December 2020 imported horses were Arabs, Thoroughbreds, Javan, Persian and Spanish. These breeds had been mixed to form what is called the Cape horse and Basuto pony which later improved to become Nooitgedacht breed. Additionally, the Thoroughbred stallions were introduced to South Africa in the 1900's for the improvement of Basuto pony (2). Thoroughbred is one of the most valuable breed of horse in the world and is used mainly for racing, but is also bred for other riding disciplines (5). Thoroughbred was developed in United Kingdom and the pedigrees of all modern Thoroughbred individuals can be traced to three stallions namely; Darley Arabian, Godolphin Arabian and Byerley Turk which were originally imported into England during $17^{\text {th }}$ and $18^{\text {th }}$ centuries. Thoroughbreds are commonly used for 
crossbreding purposes to create new breeds or to improve existing ones, and have been influential in the creation of various warmblood breeds (6).

Egypt, although not an area of origin, it is considered a focal point for breeding Arabian horses for the past 200 years (7) . El-Zahraa Stud is the biggest Egyptian governmental farm having about 500 horses and is considered the main supplier of Arabian horses for other private farms all over the Egyptian country. Maintaining higher genetic diversity within horses is needed for longterm genetic improvement and to prevent the low performance (8-10) and expression of deleterious recessive genes due to inbreeding effect $(11,12)$. Authorities for Arabian horses registry have adopted parentage testing programs for breed registration, studbook creation, and to maintain the purity of Arabians (7). Moreover, parentage test is important for global certification of our Arabian horses and to avoid breeding violations. In addition, keeping parentage records helps in prevention of animal adulteration during exportation and importation as well as detection of animal thefts. Microsatellites are considered the best markers for evaluation of genetic diversity and parentage testing in different animal species including horses $(13,14)$. Genetic diversity and parentage studies of the Arabian horses reared in Egypt based on International Society of Animal Genetics (ISAG) microsatellite markers are scanty $(15,14)$. Other microsatellite markers called TKY panel was isolated and give sufficient and reliable information for paternity testing and genetic diversity in Thoroughbred horses, which have much less heterozygosity than non-Thoroughbred horses (16). Moreover, TKY microsatellites showed multiple alleles as well as high heterozygosity among Japanese $(17,18)$ and Bhutan (19) horses. Although the use of 12 microsatellite markers of ISAG panel is useful for genetic diversity evaluation, some markers showed few alleles, low heterozygosity and a lower value for probability of exclusion $(20,16,21,13)$. So that the objectives of our study were, firstly, to conduct genetic characterization of Egyptian Arabian horses, secondly, to investigate the powerfulness of these 14 TKY markers for parentage assignment of Egyptian Arabian horses. We believe that this is the first report about the genetic diversity of Egyptian Arabian horse using TKY microsatellite panel.

\section{Materials and methods}

\section{Sample collection}

A total of 101 horse samples representing three different populations were examined, including 71 Arabian horse samples collected from E1Zahraa stud, Egyptian Agricultural Organization (EAO), Cairo, Egypt. In addition to 30 Equine DNA samples were brought for the ISAG Horse Comparison Test (HCT) 2017 and 2019 including 19 samples of Thoroughbred and 11 samples of Nooitgedacht breeds. The source of ISAG samples 2017 and 2019 are South Africa and Germany respectively. These thirty samples were used as a reference samples to compare and standardize allele sizes of TKY Panel and to represent a group of non-Arabian breeds.

\section{DNA Extraction and Microsatellite Analysis}

Total DNA from the hair follicles of the Arabian horses were extracted using EZ-10 Spin Genomic DNA Minipreps purification kit following the manufacturer's protocol. A total of 14 TKY microsatellite markers (TKY287, TKY294, TKY 297, TKY301, TKY312, TKY321, TKY325, TKY333, TKY 337, TKY341, TKY343, TKY344, TKY374 and TKY394) specific to equine were used in this study (16). TKY287, TKY321, TKY343, and TKY344 markers were labeled with FAM dye while TKY297, TKY301, TKY312, TKY337, and TKY374 markers were labeled with HEX dye. Moreover, TKY325, TKY333, TKY341, and TKY394 markers were labeled with NED dye and finally, TKY394 marker was labeled with PET dye. These four dyes allow the amplification of the 14 markers in one multiplex PCR reaction without any overlapping between the markers. TKY Panel was adjusted by using known reference samples brought for the ISAG Horse Comparison Test 2017 and 2019. Alleles were designated with alphabetical symbols from the above allele sizes. A middlesized allele was assigned as $\mathrm{M}$. The 14 TKY microsatellites were amplified in one multiplex reaction using Amplitaq Gold DNA Polymerase with Gold Buffer and $\mathrm{Mgcl}_{2}$ kit (Cat. No.: 4311816 - Applied Biosystems - USA). One multiplex PCR was performed in a total volume of $20 \mu \mathrm{l}$ of the following mixture: $20-50 \mathrm{ng}$ of equine genomic DNA, each forward/reverse primer at $0.3 \mu \mathrm{M}$, 
$200 \mu \mathrm{M}$ of dNTPs, $2 \mu \mathrm{l}$ of $10 \mathrm{x}$ reaction buffers; and $0.3 \mathrm{U}$ of $\mathrm{rTaq}$ polymerase. PCR amplification entailed initial denaturation $\left(95^{\circ} \mathrm{C}, 10 \mathrm{~min}\right), 30$ cycles of $30 \mathrm{sec}$ each at $95^{\circ} \mathrm{C}, 55^{\circ} \mathrm{C}$ and $60 \mathrm{sec}$ at $72^{\circ} \mathrm{C}$, and then $10 \mathrm{~min}$ at $72^{\circ} \mathrm{C}$ for final extension in a thermocycler (T100-BioRAD, UK). Fragment sizes of microsatellite alleles were determined using Genetic analyzer 3500 (Applied Biosystem-USA) with the aid of Liz standard (Cat. No.: 4322682 Applied Biosystems - USA). The data obtained is further analyzed using Gene Mapper V 4.1 software (Applied Biosystem- USA).

\section{Data analysis}

\section{Marker polymorphisms and population diversity}

Number of alleles $\left(N_{A}\right)$, effective number of alleles $\left(N_{e}\right)$, private alleles, observed heterozygosity $\left(H_{O}\right)$ and expected heterozygosity $\left(H_{E}\right)$ were calculated by using GENALEX version 6 software (22). Polymorphic information content (PIC) was calculated by using CERVUS version 3 software (23). Hardy Weinberg equilibrium ( $H W E)$, fixation coefficient of an individual within a subpopulation $\left(F_{I S}\right)$ were estimated by GENEPOP version 3.4 program (24). The power of exclusion (PE) and combined power of exclusion (CPE) of the 14 studied loci for Arabian population were calculated from allele frequencies using GENALEX version 6 software (22).

\section{Results}

\section{Marker polymorphisms and populations} diversity

The total numbers of alleles were 115,88 and 78 for Arabian, Nooitgedacht and Thoroughbred, respectively. The comparison and standardization for alleles size and frequency of the 14 TKY loci in the Arabian and the two reference horse populations (Nooitgedacht and Thoroughbred) was shown in the supplementary figure 1 . The polymorphism of 14 TKY markers across the Arabian population showed moderate values for genetic diversity parameters $\left(N_{A}\right.$ =8.143, $N_{e}=3.694, H_{O}=0.599, H_{E}=0.691$ and $P I C=0.636)$. Arabian population showed high and positive value of $F_{I S}(0.129)$. Locus TKY394 showed higher values for the most of diversity parameters $\left(N_{A}=11, N e=7.638, H_{O},=0.676, H_{E}=0.875\right.$ and $P I C=0.855)$. The highest number of private alleles was recorded for TKY344 locus, while TKY301 and TKY374 loci recorded non-private alleles. Locus TKY337 showed the lowest values for all diversity indices $\left(N_{A}=5, N_{e}=1.861, H_{O}=0.310, H_{E}=\right.$ 0.466 and PIC $=0.421$ ). Moreover, it significantly deviated from $H W E$ and recorded the highest $F_{I S}$ value (0.330). All loci except TKY297 and TKY325 showed a significant deviation from HWE (Table 1). The frequency of the five alleles of locus TKY337 in the Arabian and in the two reference populations (Nooitgedacht and Thoroughbred) was shown in Figure 1. Allele $177 \mathrm{bp}$ recorded very high frequency
Figure 1: Allele's frequency of locus TKY337 in the Arabian and the two reference horse populations (Nooitgedacht and Thoroughbred)

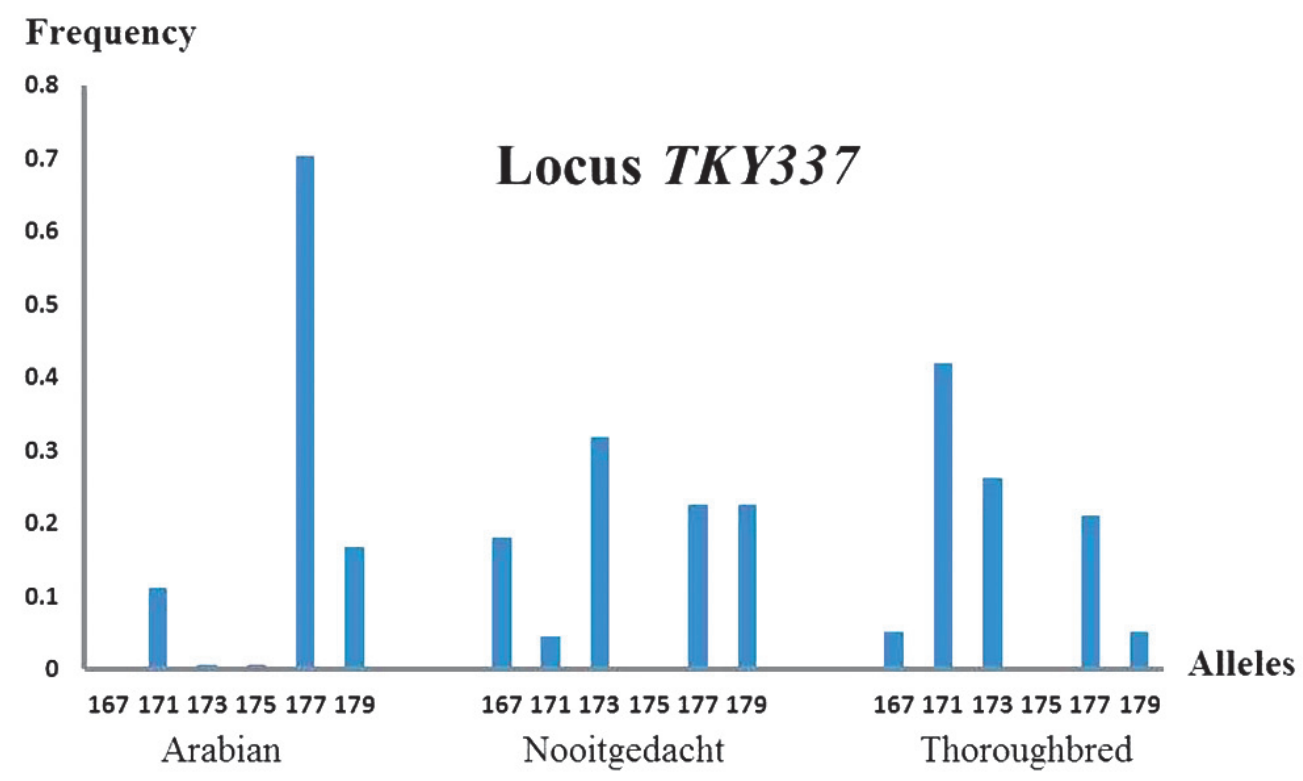


Table 1: Number of alleles $(\mathrm{Na})$ effective number of alleles $(\mathrm{Ne})$, Observed heterozygosity $\left(\mathrm{H}_{\mathrm{O}}\right)$, expected heterozygosity $\left(H_{E}\right)$, polymorphic information content $(P I C), \mathrm{F}_{I S}$, and Hardy Weinberg equilibrium (HWE) across the Arabian population

\begin{tabular}{cccccccccc}
\hline Locus & $\boldsymbol{N}_{\boldsymbol{A}}$ & $\boldsymbol{N e}$ & $\begin{array}{c}\text { Private } \\
\text { alleles }\end{array}$ & $\boldsymbol{H}_{\boldsymbol{O}}$ & $\boldsymbol{H}_{\boldsymbol{E}}$ & $\boldsymbol{P I C}$ & $\boldsymbol{P E}$ & $\boldsymbol{F}_{\text {IS }}$ & $\boldsymbol{H W E}$ \\
\hline TKY287 & 9 & 3.548 & 2 & 0.563 & 0.723 & 0.689 & 0.720 & 0.215 & $* * *$ \\
TKY294 & 7 & 2.531 & 3 & 0.592 & 0.609 & 0.527 & 0.487 & 0.022 & $* * *$ \\
TKY297 & 7 & 2.515 & 1 & 0.549 & 0.607 & 0.563 & 0.565 & 0.088 & $\mathrm{~ns}$ \\
TKY301 & 6 & 2.093 & 0 & 0.408 & 0.526 & 0.466 & 0.439 & 0.218 & $* * *$ \\
TKY312 & 6 & 2.891 & 1 & 0.648 & 0.659 & 0.604 & 0.588 & 0.010 & $* * *$ \\
TKY321 & 8 & 2.342 & 1 & 0.577 & 0.577 & 0.546 & 0.573 & -0.008 & $* * *$ \\
TKY325 & 8 & 4.583 & 1 & 0.634 & 0.787 & 0.748 & 0.758 & 0.189 & $\mathrm{~ns}$ \\
TKY333 & 9 & 3.902 & 3 & 0.718 & 0.749 & 0.705 & 0.711 & 0.034 & $* * *$ \\
TKY337 & 5 & 1.861 & 1 & 0.310 & 0.466 & 0.421 & 0.400 & 0.330 & $* * *$ \\
TKY341 & 8 & 3.858 & 3 & 0.676 & 0.746 & 0.696 & 0.685 & 0.087 & $* * *$ \\
TKY343 & 12 & 5.934 & 5 & 0.718 & 0.837 & 0.814 & 0.857 & 0.136 & $* *$ \\
TKY344 & 11 & 4.292 & 7 & 0.634 & 0.772 & 0.578 & 0.772 & 0.174 & $* * *$ \\
TKY374 & 8 & 3.779 & 0 & 0.676 & 0.741 & 0.685 & 0.673 & 0.081 & $* * *$ \\
TKY394 & 11 & 7.638 & 3 & 0.676 & 0.875 & 0.855 & 0.895 & 0.222 & $* * *$ \\
Mean & 8.143 & 3.694 & 2.214 & 0.599 & 0.691 & 0.636 & 0.959 & 0.128 & \\
\pm ISE & \pm 0.553 & \pm 0.425 & \pm 0.521 & \pm 0.031 & \pm 0.032 & \pm 0.31 & 0.006 & \pm 0.027 & \\
\hline ns = not significant, $*=P<0.05, * *=P<0.01, * * * P<0.00$ & & & & & &
\end{tabular}

(0.704) in Arabian comparing to Nooitgedacht (0.227) and Thoroughbred (0.211) populations. The parentage assignment of the Arabian population using a combination of the 14 loci was very successful indicated by their high power of exclusion. The combined probability of exclusion (CPE) was 0.9999 in case of excluding putative parent pair. The highest PE value was reported for TKY394 while the lowest for TKY337 loci.

\section{Discussion}

\section{Marker polymorphisms and populations diversity}

This study presents the first description of genetic characterization of Egyptian Arabian horses based upon the TKY microsatellites panel. The number of alleles $\left(N_{A}\right)$ and the frequency distribution of these alleles $\left(N_{e}\right)$ in any population could tell us how informative a locus is. The number of alleles $\left(N_{A}\right)$ of our Arabian population was higher than that of Thoroughbred breed of Tozaki study (16) for the most of studied TKY markers except for TKY301 and TKY325 loci (16). The means for $H_{O}(0.599)$ and $H_{E}(0.691)$ of our Arabian horses were higher than those of Kobayashi study for Misaki Japanese horses ( $H_{O}=0.509$ and $H_{E}=0.497$ ) based on a combination of 32 microsatellites from ISAG and TKY panels (18). In contrast, the $H_{O}$ and $H_{E}$ of our Arabians were lower than both of Thoroughbred breed ( $H_{O}=0.731$ and $H_{E}=0.747$ ) based on $15 \mathrm{TKY}$ markers (16) and traditional horse breeds of Bhutan $\left(H_{O}=0.790\right.$ and $\left.H_{E}=0.780\right)$ based on a combination of 29 microsatellite markers from ISAG and TKY panels (19).

The high mean of $N_{A}$ and lower mean of $N_{e}$ and the positive mean for $F_{I S}$ in addition to 12 out of 14 loci showed significant deviation from $H W E$ might indicate that there was non-random mating among our Arabian horses in El-Zahraa stud and a selection program favoring some morphological characters might be practiced on this population. TKY337 locus recorded the lowest values for all diversity indices and significantly deviated from $H W E$ and showed the highest and positive value for $F_{I S}(0.330)$ in our Arabian horses. Moreover, only one allele (177 bp) out of the five reported alleles of the TKY337 locus recorded a very high frequency as shown in Figure 1. This might be attributed to that allele (177 bp) might be under some morphological or beauty related traits of 
selective interest in our Arabian population in El-Zahraa stud. In respect to population genetic diversity, the Arabian population showed high inbreeding level indicated by the higher and positive value of $F_{I S}(0.129)$.

The CPE value of the 14 TKY microsatellite loci of our Arabian horses was 0.9999 which is higher than the required value by the International Stud Book Committee (0.9995), So the 14 TKY microsatellites are suitable for evaluation of genetic diversity not only for Thoroughbred populations (16), but also for our Egyptian Arabian horses. In this study, seven microsatellite loci (TKY287, TKY312, TKY325, TKY333, TKY341, TKY343, TKY374 and TKY394) had high PIC values (>0.600). High level of CPE (>0.9999) can be achieved using only six of the 14 loci (TKY287, TKY325, TKY333, TKY343, TKY344 and TKY394) as shown in (Figure 2), which makes these six markers highly valuable for parentage testing in Arabian horses. Ten microsatellite loci at least was suggested to be used for achieving maximum exclusion in horses (25), but our results showed that fewer loci can achieve relatively high power of exclusion, similar result was recorded by Sereno et al. (26). Two markers, TKY301 and TKY337 were found to have a PIC value lower than 0.500 for the studied Arabian population. As these two markers are considered less informative, they can easily be excluded from parentage testing for the Arabian horses with no significant loss of exclusion power.

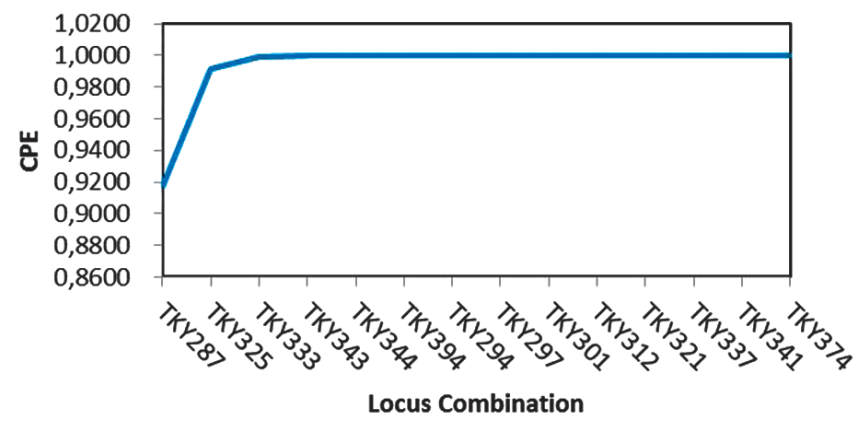

Figure 2: Combined probability of exclusion (CPE) as a function of the number of 14 TKY microsatellite loci for the Arabian horse population

\section{Conclusion}

The 14 TKY markers provide a powerful and efficient tool for genetic diversity and parentage studies in the Arabian horses of El-Zahraa stud. Locus TKY337 should be interpreted with caution and should be analyzed in further studies in different Arabian horse populations to test if it is linked to any morphological traits or not. Finally, the high $F_{I S}(0.129)$ of Arabian horses in El-Zahraa stud should be corrected by modifying mating system through avoiding excessive use of certain sires. The data presented in our study will provide the horse breeders with an effective tool for confirming parentage and lineages. Genetic diversity analysis will also generate valuable data necessary for the conservation of this valuable horse breed.

\section{Acknowledgment}

The current work was conducted according to the protocols that were approved by the Committee of Animal Care and Welfare, Benha University, Egypt with an approval number: BUFVTM 03-092019.

RM-E, ME-A, EA-E and HA-A planned and designed the study. MA-S collected the hair samples and extracted the DNA. MA-S, HA-A and NM-H performed the microsatellite genotyping. SI-R, HA-A and MA-S performed the analysis and interpretation of the data. SI-R and MA-S drafted the article and revised it critically for important intellectual content. All authors read and approved the manuscript final version to be published. The authors declared that they have no conflict interests.

We thank the Egyptian Agriculture Organization for providing Arabian horse samples of El-Zahraa stud. This work was financially supported by the Animal Health Research Institute (AHRI) of Agricultural Research Centre, Dokki, Giza, Egypt.

\section{References}

1. Khanshour A, Conant E, Juras R, Cothran EG. Microsatellite analysis of genetic diversity and population structure of Arabian horse populations. J Hered 2013; 104: 386-98.

2. Cothran E, Van Dyk E. Genetic analaysis of three South African horse breeds. J S Afr Vet Assoc 1998; 69: 120-5.

3. Bower MA, McGivney BA, Campana MG, et al. The genetic origin and history of speed in the Thoroughbred racehorse. Nat Commun 2012; 3: art. 643. doi: $10.1038 /$ ncomms 1644

4. Wallner B, Palmieri N, Vogl C, et al. Y chromo- 
some uncovers the recent oriental origin of modern stallions. Curr Biol 2017; 27: 2029-35.

5. Bower MA, McGivney BA, Campana MG, et al. The genetic origin and history of speed in the Thoroughbred racehorse. Nat Commun 2012; 3: 1-8.

6. Kay J, Vamplew W. Encyclopedia of British horse racing. Routledge. 2012.

7. Hudson W. Whole-loop mitochondrial DNA D-loop sequence variability in Egyptian Arabian equine matrilines. PloS One 2017; 12: e0184309. doi: 10.1371/journal.pone.0184309

8. Vicente A, Carolino N, Gama L. Genetic diversity in the Lusitano horse breed assessed by pedigree analysis. Livest Sci 2012; 148: 16-25.

9. Curik I, Ferenčaković M, Sölkner J. Genomic dissection of inbreeding depression: a gate to new opportunities. Rev Bras Zootec 2017; 46: 773-82.

10. Todd ET, Ho SY, Thomson PC, Ang RA, Velie BD, Hamilton NA. Founder-specific inbreeding depression affects racing performance in Thoroughbred horses. Sci Rep 2018; 8: art. 6167. doi: 10.1038/s41598-018-24663-x

11. Tarr CJ, Thompson PN, Guthrie AJ, Harper CK. The carrier prevalence of severe combined immunodeficiency, lavender foal syndrome and cerebellar abiotrophy in Arabian horses in South Africa. Equine Vet J 2014; 46: 512-4.

12. Ela NAA, Khalid A, Ahmed HA, Brooks SA. Molecular detection of severe combined immunodeficiency disorder in Arabian horses in Egypt. $\mathrm{J}$ Equine Vet Sci 2018; 68: 55-8.

13. Khanshour AM, Conant EK, Juras R, Cothran EG. Microsatellite analysis for parentage testing of the Arabian horse breed from Syria. Turk J Vet Anim Sci 2013; 37: 9-14.

14. Sargious MA, Bakry H, El-Shawarby R, Ahmed HA. Parentage testing of Arabian horse in Egypt using microsatellite DNA typing. Benha Vet Med J 2014; 1: 100-8.

15. Mahrous KF, Hassanane M, Mordy MA, Shafey HI, Hassan N. Genetic variations in horse using microsatellite markers. J Genet Eng Biotechnol 2011; 9: 103-9.

16. Tozaki T, Kakoi H, Mashima S, et al. Population study and validation of paternity testing for
Thoroughbred horses by 15 microsatellite loci. J Vet Med Sci 2001; 63: 1191-7.

17. Tozaki T, Takezaki N, Hasegawa T, et al. Microsatellite variation in Japanese and Asian horses and their phylogenetic relationship using a European horse outgroup. J Hered 2003; 94: 374-80.

18. Kobayashi I, Akita M, Takasu M, et al. Genetic characteristics of feral Misaki horses based on polymorphisms of microsatellites and mitochondrial DNA. J Vet Med Sci 2019; 81: 707-11.

19. Dorji J, Tamang S, Tshewang T, Dorji T, Dorji TY. Genetic diversity and population structure of three traditional horse breeds of Bhutan based on 29 DNA microsatellite markers. PloS One 2018; 13: e0199376. doi: 10.1371/journal. pone. 0199376

20. Achmann R, Huber T, Wallner B, Dove P, Müller M, Brem G. Base substitutions in the sequences flanking microsatellite markers HMS3 and ASB2 interfere with parentage testing in the Lipizzan horse. Anim Genet 2001; 32: e52. doi: 10.1046/j.1365-2052.2001.0647k.x

21. Monies D, Abu Al Saud N, Sahar N, Meyer B. Population studies and parentage testing for Arabian horses using 15 microsatellite markers. Anim Genet 2011; 42: 225-6.

22. Peakall R, Smouse PE. GENALEX 6: genetic analysis in Excel. Population genetic software for teaching and research-an update. Bioinformatics 2012; 28: 2537-9.

23. Huang K, Mi R, Dunn DW, Wang T, Li B. Performing parentage analysis in the presence of inbreeding and null alleles. Genetics 2018; 210: 1467-81.

24. Rousset F. GENEPOP (version 1.2): population genetics software for exact tests and ecumenicism. J Hered 1995; 86: 248-9.

25. Ellegren H, Johansson M, Sandberg K, Andersson L. Cloning of highly polymorphic microsatellites in the horse. Anim Genet 1992; 23: 133-42.

26. Sereno FTPdS, Sereno JRB, Vega-Pla JL, Delgado JV. DNA testing for parentage verification in a conservation nucleus of Pantaneiro horse. Genet Mol Biol 2008; 31: 64-7. 


\section{GENSKA RAZNOVRSTNOST EGIPČANSKIH KONJ ARABSKE PASME IZ KOBILARNE EL-ZAHRAA NA PODLAGI 14 MIKROSATELITSKIH OZNAK TKY}

M. A. N. Sargious, Ragab M. El-Shawarby, Mohamed E. Abo-Salem, E. A. EL-Shewy, H. A. Ahmed, N. M. Hagag, S. I. Ramadan

Izvleček: Nameni raziskave so bili genetska karakterizacija egipčanskih konj arabske pasme na podlagi 14 mikrosatelitskih označevalecv TKY ter raziskava moči 14 označevalcev TKY za dodelitev staršev arabskih konj. S pomočjo 14 mikrosatelitskih označevalcev TKY je bilo analiziranih 101 vzorcev konj (arabski = 71, čistokrvni = 19 in konji Nooitgedacht = 11). Produkte PCR so analizirali s pomočjo elektroforeze na genskem analizatorju 3500 s pomočjo Liz standarda. Osnovne mere velikosti alela in genske raznovrstnosti so bile izračunane s pomočjo programske opreme za bioinformatiko. Polimorfizem označevalcev TKY $\checkmark$ arabski populaciji je pokazal zmerne vrednosti za parametre genske raznolikosti; število alelov $\left(N_{A}\right)=8,143$, efektivno število alelov $\left(N_{e}\right)=3,694$, opazovana heterozigotnost $\left(H_{0}\right)=0,599$, pričakovana heterozigotnost $\left(H_{E}\right)=0,691$, polimorfna informacijska vsebina $(P I C)=0,636$ in Inbriding koeficient $\left(F_{I S}\right)=0,128$. Skupna vrednost verjetnosti izključitve (CPE) 14 mikrosatelitskih lokusov $T K Y$ njihovih arabskih konj je bila 0,9999. Rezultati te raziskave potrjujejo uporabnost in učinkovitost mikrosatelitske plošče TKY za oceno genetske raznovrstnosti in starševske pripadnosti egipčanskih arabskih konj.

Ključne besede: arabskikonji; genskaraznolikost; mikrosatelit; markerji TKY 

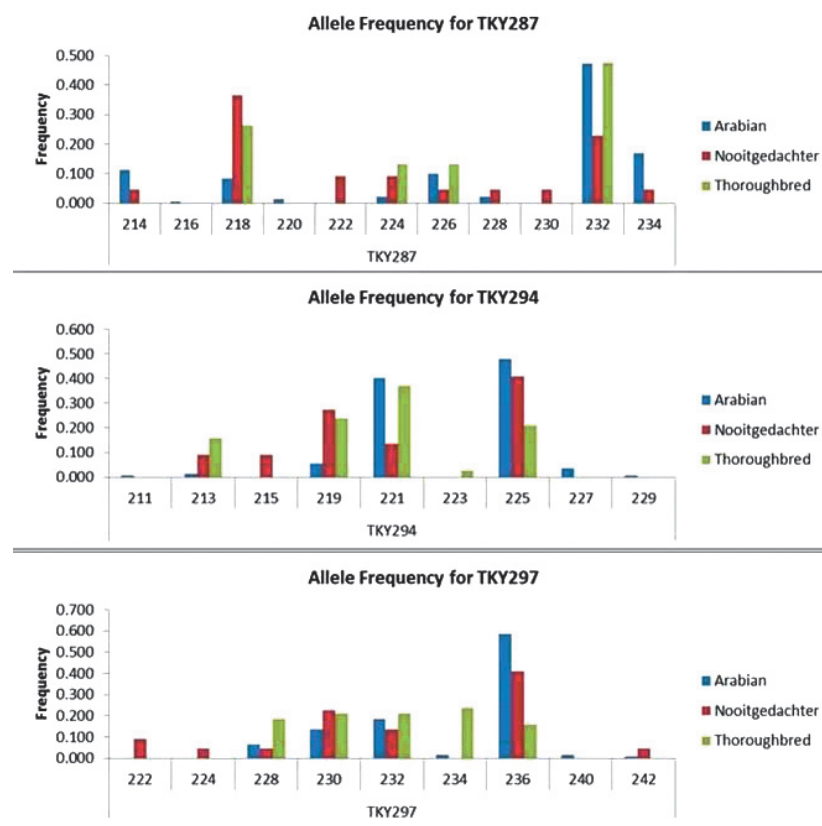

Supplementary figure 1 (a)
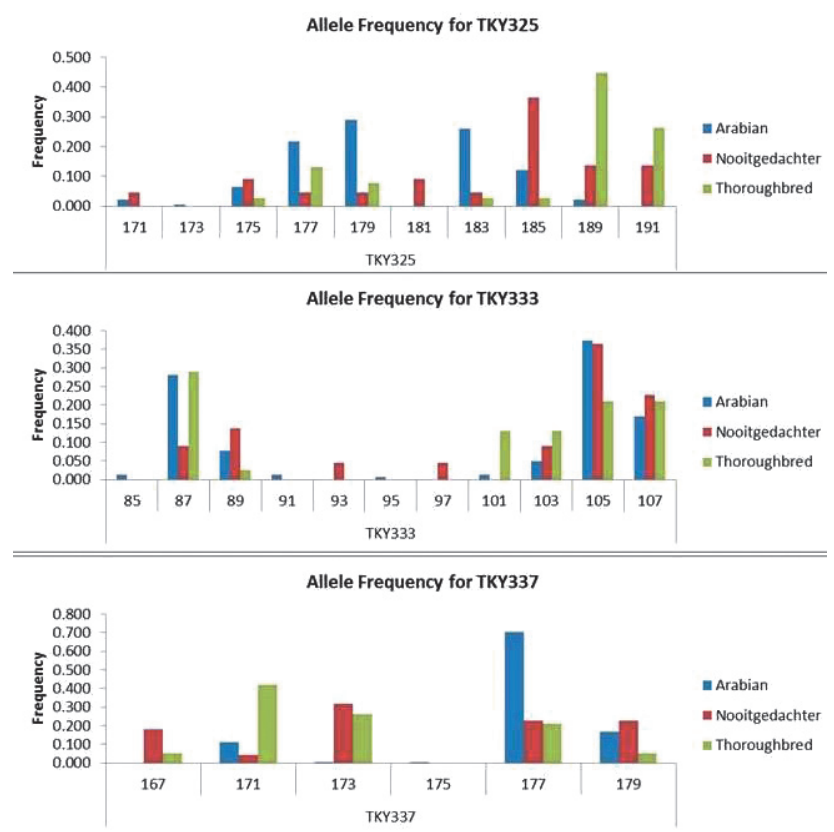

Supplementary figure 1 (c)

Allele Frequency for TKY374

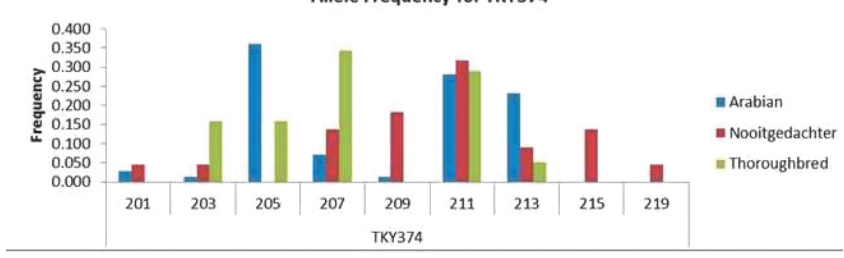

Allele Frequency for TKY394

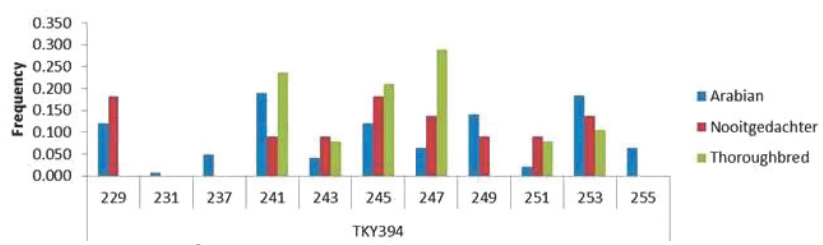

Supplementary figure 1 (e)
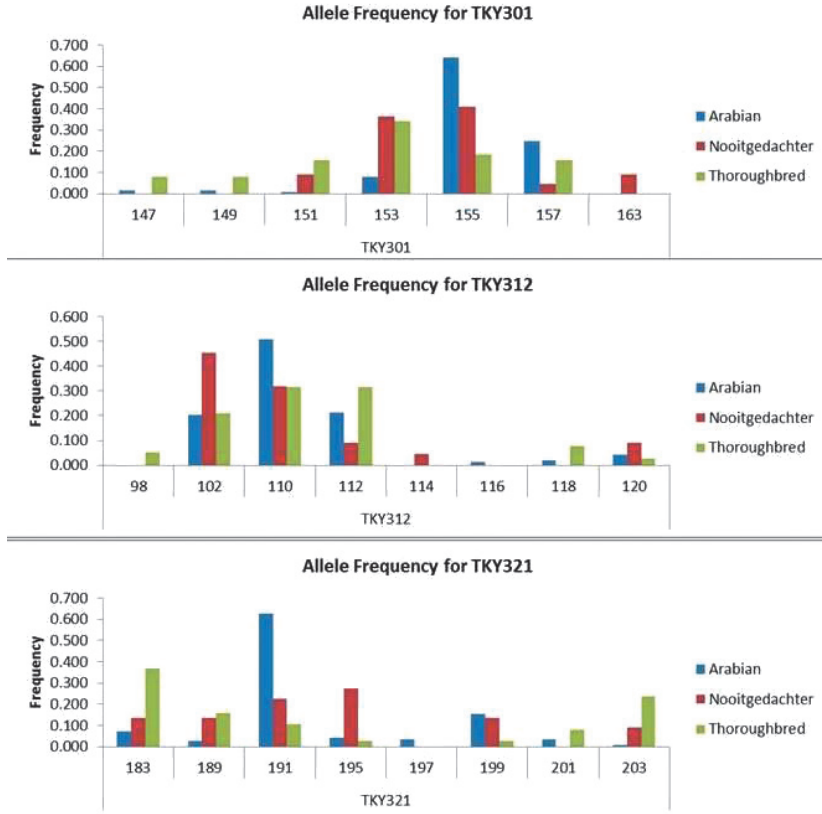

Supplementary figure 1 (b)
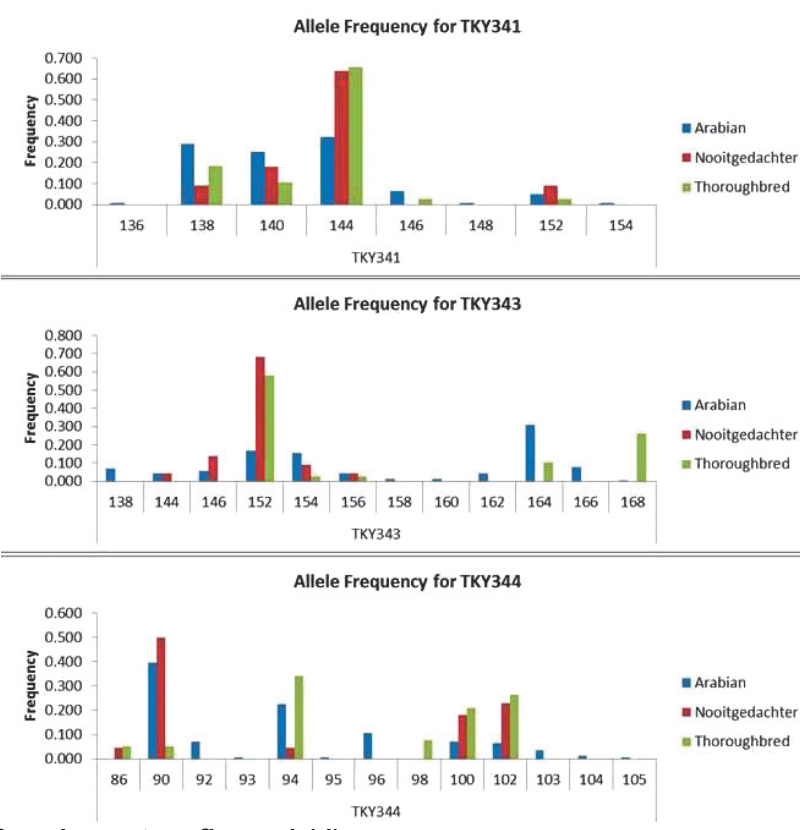

Supplementary figure 1 (d)

Supplementary Figure 1 Allele's size and frequency of the 14 TKY loci in the Arabian and the two reference horse populations (Nooitgedacht and Thoroughbred)

a) Allele's size and frequency of TKY287, TKY294 and TKY297 loci b) Allele's size and frequency of TKY301, TKY312 and TKY321 loci c) Allele's size and frequency of TKY325, TKY333 and TKY 337 loci d) Allele's size and frequency of TKY341, TKY343 and TKY344 loci e) Allele's size and frequency of TKY374 and TKY394 loci 